Висновки. Представлений у статті аналіз особливостей реалізації ідей педагогіки партнерства засвідчив доцільність застосування системного підходу до вирішення цієї проблеми. У межах зазначеного підходу встановлено, що для успішного впровадження ідей педагогіки партнерства необхідно забезпечити: різноманітність суб'єктів партнерських взаємодій; розширення сфери, де реалізуються партнерські взаємодії; урізноманітнення партнерських взаємодій в управлінні процесами в закладах освіти; врахування рівня розвитку освітніх систем.

Перспективи подальших досліджень. Водночас, зважаючи на виокремлені вище умови ефективної реалізації ідей педагогіки партнерства, важливим є дослідження проблеми визначення відповідних їм форм і методів педагогічної діяльності й управління освітою.

\section{СПИСОК ВИКОРИСТАНОЇ ЛІТЕРАТУРИ}

1. Мармаза О. І. Менеджмент освітньої організації. Харків : ТОВ «Щедра садиба», 2017. 126 с.

2. Нова українська школа. Концептуальні засади реформування середньої школи. 2016. URL: https:// mon.gov.ua/storage/app/media/zagalna\%20serednya/ nova-ukrainska-shkola-compressed.pdf (дата звернення: 22.09.2020).

УДК 377.02

DOI: 10.37026/2520-6427-2020-103-3-32-35
3. Пастовенський О. В. Особливості реалізації функцій управління освітою в умовах розвитку освітніх систем. Народна освіта : електронне наукове фахове видання. 2019. Вип. 3 (18). URL: https://www.narodnaosvita. kiev.ua/?page_id=5532 (дата звернення: 22.09.2020).

4. Пастовенський О. В. Синергетичний сценарій розвитку ефективних освітніх систем. Вісник Житомирського державного університету імені Івана Франка. Педагогічні науки. 2016. Вип. 2(84). С. 102-106.

5. Про затвердження Порядку проведення інституційного аудиту закладів загальної середньої освіти (зі змінами) : Наказ Міністерства освіти і науки України від 09.01.2019 p. № 17. 2019. URL: https://zakon.rada.gov.ua/ laws/show/z0250-19\#Техt (дата звернення: 20.09.2020).

6. Про повну загальну середню освіту : Закон України від 13.07.2020 р. № 764-IX. URL: https:// zakon.rada.gov.ua/laws/show/463-20\#Text (дата звернення: 21.09.2020).

7. Про схвалення Концепції реалізації державної політики у сфері реформування загальної середньої освіти «Нова українська школа» на період до 2029 року : розпорядження Кабінету Міністрів України від 14.12.2016 р. № 988-p. 2016. URL: https://zakon.rada.gov.ua/laws/show/ 988-2016-\%D1\%80\#Техt (дата звернення: 21.09.2020).

Дата надходження до редакиіiі: 24.09.2020 p.

Тетяна ЯкИМОвИЧ,

кандидат педагогічних наук,

стариий науковий співробітник,

доцент кафедри теорії і методики

технологічної освіти

Національного педагогічного університету

імені М. П. Драгоманова, м. Київ

Ірина ЗІНЧУК,

викладач кафедри іноземних мов

Національного університету «Львівська політехніка»

\title{
ІНТЕГРАТИВНИЙ ПІДХІД ДО ФОРМУВАННЯ ПРОФЕСІЙНОГО МИСЛЕННЯ МАЙБУТНІХ ФАХІВЦІВ ТЕХНІЧНИХ СПЕЦІАЛЬНОСТЕЙ У ПРОЦЕСІ НАВЧАННЯ В ЗАКЛАДІ ВИЩОЇ ОСВІТИ
}

У статті обтрунтовано інтегративний підхід, на основі якого розглянуто сутність та властивості професійного мислення із погляду різних наук (філософія, психологія, педагогіка). Виокремлено властивості професійного мислення майбутніх фахівиів технічних спеціальностей, щзо формуються у процесі навчання у закладі вищої освіти. Доведено, щзо формування професійного мисленнямайбутніх фахівців технічних спеціальностей у процесі навчання передбачає вирішення проблемних завдань, аналіз ситуацій, прийняття професійних рішень, вибір способів діяльності.

Ключові слова: інтегративний підхід, професійне мислення, професійна діяльність, професійна ситуачия, освітній проиес.

Обоснованно интегративный подход, на основе которого рассмотрена сущность и свойства профессионального мышления с позиций различных наук 
(философия, психология, педагогика). Показано, что формирование профессионального мышления будущих специалистов технических специальностей в прочессе обучения предполагает решение проблемныхх задач, анализ профессиональных ситуащий, принятия профессиональных решений, выбор способов деятельности. Выделены свойства профессионального мышления будущих специалистов технических специиальностей, которые формируются в образовательном прочессе.

Ключевые слова: интегративный подход, профессиональное мышление, профессиональная деятельность, профессиональная ситуация, образовательный процесс.

The aim of the article is to clarify the essence of professional thinking and justify an integrative approach to the formation of professional thinking of future professionals of technical specialties from various scientific positions. It is defined as mental ability, process, system, intellectual skills and integral quality. The integrative approach involves the study of the essence and properties of professional thinking from the perspective such sciences as philosophy, psychology, pedagogy. From the perspective of philosophy, thinking is the basis for the formation of worldview and involves the understanding of being as a whole. Worldview integrates knowledge, ideals, goals, hopes, desires, beliefs, emotions, feelings, views on the meaning and purpose of life, which determine human thinking and activity. From the perspective of psychology, there is an organic connection between individual thinking processes, feelings and will.

The development of holistic logical thinking is not possible without taking into account the integration processes: both in the human psyche and in the learning process. From the perspective of pedagogy, the formation of thinking is built as a holistic system of knowledge. The properties and structure of professional thinking of specialists in different fields are due to different characteristics of the professional activity. Professional thinking is a process of generalized and indirect reflection of a person's professional reality, which is carried out using specific to each profession techniques for solving professional problems. Its common features involve the process of identifying, understanding and solving professional problems.

In educational process, such functions of thinking as understanding (conceptual function), the function of problems and tasks solving, the function of goal formation and the reflexive function are formed. An integrative approach from the perspective of pedagogy includes integration of content, methods and means of developing professional thinking in the educational process. The formation of professional thinking of future professionals in the learning process involves solving problems, analyzing professional situations, making professional decisions, choosing ways of working, etc.

Key words: integrative approach, professional thinking, professional activity, professional situation, educational process.

Постановка проблеми. Кожне нове покоління $є$ складовою сформованої на даний момент системи освіти, що відображає історичні, соціальні, економічні та інші особливості епохи. У сучасних умовах проблема формування творчої, високоосвіченої, неординарної й ініціативної особистості, яка прагне до самореалізації та самовдосконалення, набуває особливого значення.
Оскільки життя людини в суспільстві, як і їі світогляд, за своїм змістом мають інтегративний характер, то і система знань, умінь та навичок здобувачів освіти також повинна бути інтегративною. При цьому необхідно враховувати, що жодна окремо взята навчальна дисципліна неспроможна забезпечити формування професійного мислення майбутніх фахівців технічних спеціальностей, тобто інтегративний підхід забезпечує органічне поєднання різноманітних знань і методів пізнання на науково визначеній основі. Загальні відношення, зв'язки, обумовленості розкриваються в кожному навчальному предметі шляхом певних специфічних методів, мають власний понятійний апарат та внутрішній зміст.

Таким чином, лише на основі науково обгрунтованого інтегративного підходу при визначенні змісту, форм та методів навчання можна сформувати професійне мислення майбутніх фахівців технічних спеціальностей, що відповідатиме вимогам сучасного суспільства.

Аналіз наукових досліджень і публікацій. Проблеми формування та активізації мислення за допомогою оптимізації змісту, форм та методів навчання у різні часи досліджувалися низкою психологів (Д. Богоявленська, Л. Засєкіна, Г. Костюк, О. Леонтьєв, С. Максименко, А. Маркова, Н. Пов'якель та ін.) та педагогів (Ю. Бабанський, Г. Ващенко, С. Гончаренко, В. Давидов, І. Лернер, І. Козловська, П. Лузан, М. Махмутов та ін.).

Донині немає однозначності щодо визначення сутності професійного мислення. Так, його трактують як розумову здатність (С. Гончаренко [2]), інтегральну якість (І. Козловська [4]), процес (А. Маркова [5]), систему (В. Свистун, А. Зуєва, Е. Луговська [6]), інтелектуальні вміння (Т. Якимович [7]) тощо. Зокрема, науковці та дослідники використовують різні підходи до класифікації видів мислення, його взаємодії з іншими людськими функціями, критерії оцінки мисленнєвої діяльності.

Незважаючи на чималу кількість досліджень, проблема формування професійного мислення саме майбутніх фахівців технічних спеціальностей поки не знайшла достатнього висвітлення в науковій літературі, зокрема недостатня увага приділена дослідженню конкретних підходів до формування професійного мислення таких фахівців. Це дозволяє виокремити питання інтегративного підходу до професійного мислення із загальної проблеми для більш грунтовного розгляду.

Мета статті - з'ясувати сутність професійного мислення та обгрунтувати значення інтегративного підходу до формування професійного мислення майбутніх фахівців технічних спеціальностей із різних наукових позицій.

Виклад основного матеріалу. Інтегративний підхід передбачає дослідження сутності та властивостей професійного мислення із позицій різних наук, таких як філософія, психологія, педагогіка та ін.

Із позицій філософії, мислення є основою формування світогляду і передбачає розуміння особистістю буття як цілісності та усвідомлення законів у загальному та окремих проявах. У системі знань доцільно відрізняти головне (уявлення про буття як ціле, про природу і сенс цього буття, про його основні рушійні сили і закони) та похідне, часткове (яке стосується окремих частин буття або окремих його явищ). Залежно від того, як здобуті та приведені у систему знання про світ, світогляд може бути науковим (складатися зі 
знань, здобутих за допомогою перевірених і продуманих методів, свідомо приведених до певної системи й обгрунтованих логічно) та ненауковий (знання здобуті без застосування спеціальних методів, логічно необгрунтовані, не приведені в систему). Світогляд інтегрує в собі знання, ідеали, цілі, сподівання, бажання, переконання, емоції, почуття, погляди на сенс і мету життя, котрі визначають мислення та діяльність людини. Отже, серед різноманітних засобів людського пізнання вагоме місце посідає розвиток мислення.

Психіка людини надзвичайно складна і багатогранна, і для виховання повноцінної особистості необхідно враховувати всі ці грані та не забувати про єдність людської особистості. Психологічний аспект формування мислення та взаємозв'язку знань одним iз перших обгрунтував Й. Гербарт [8]. Він стверджував, що при взаємопов'язаному викладанні матеріалу молодь отримує навички швидше і повноцінніше, ніж при ізольованому вивченні предметів. Особливого значення Гербарт надавав узгодженості, систематичності знань, оскільки, на його думку, безсистемність знання веде до безсистемності й суперечностей у вдачі та поведінці людини. Тому основне завдання навчання полягає у виробленні в учнів системи високовартістних знань і повноцінних, багатогранних інтересів. В основу цих тверджень покладено одну із тез психології про органічність зв'язку між окремими процесами мислення, почуттями і волею. Відповідно розвиток цілісного логічного мислення неможливо уявити без урахування інтеграційних процесів: як у людській психіці, так і в освітньому процесі.

На основі психологічних та філософських позицій низка вчених, зокрема Г. Ващенко [1], розглядали проблему формування мислення як цілісної системи знань. Г. Ващенко вважав певним обмеженням зведення Й. Гербартом виховання людини лише до інтелектуального, так само як і педагогічні погляди Сократа, котрий зводив мораль до знань, уважаючи iii мудрістю. Основне в людині, на думку Г. Ващенка, не знання самі по собі, навіть не їх грунтовність і систематичність, а характер і добра воля людини. Але незмінним залишається гербартівське [8] правило в навчанні йти від відомого до невідомого, пов'язане 3 тим, що кожне нове враження включається в суму попередніх і так чи інакше контактує 3 ними.

У розумовому вихованні Г. Ващенко акцентує увагу на змісті та формі навчання, причому під змістом він розуміє складну систему знань, а під формою ті властивості інтелекту, які враховуються в освітньому процесі. Аналізуючи дві основні течії в педагогіці, вчений виділяє їх особливості. Для першої течії характерна перевага змісту навчання, адже в іiї основі лежить вивчення основ природничо-математичних наук і навчальних предметів, пов'язаних з практикою, для другої основна мета навчання полягає у розвитку культури самих здібностей мислення (формальних властивостей інтелекту), здатності логічно мислити, обгрунтовувати свої думки, висловлювати їх у чіткій та зрозумілій формі.

До вищих інтелектуальних процесів належить логічне мислення, яке передусім полягає в переробці вражень, отриманих людиною. Внаслідок цього формуються поняття, міркування або ж їх система. Г. Ващенком [1] виокремлено такі відмінності в розвитку логічного мислення: залежність мислення від ситуації, тобто різна течія мисленнєвих процесів, залежно від зовнішніх умов, наприклад, типової чи критичної для людини ситуації; вирізняється теоретично чи практично спрямоване мислення, його вузькість чи широта; співвідношення аналізу і синтезу в процесі формування мислення.

До середини XX ст. професійне мислення було складовою загального мислення. Сучасні дослідження доводять, що властивості та структура професійного мислення фахівців різних галузей зумовлені різними характеристиками самої професійної діяльності. 3окрема, за визначенням А. Маркової, професійне мислення $є$ процесом узагальненого й опосередкованого відображення людиною професійної реальності, яке здійснюється за допомогою специфічних для кожної професії прийомів вирішення професійних завдань. Загальними його ознаками є процес виявлення, осмислення і розв'язання професійних завдань [5, с. 86]. Психолого-педагогічні розробки з проблем формування професійного мислення особистості підкреслюють важливість процесу інтеграції рис особистості.

Вивчення мислення із позицій педагогічної науки виявили, що в освітньому процесі формуються такі функції мислення, як: розуміння (понятійна функція), функція розв'язання проблем і завдань, функція цілеутворення й рефлексивна функція. Основними операціями мислення $є$ аналіз і синтез. Єдність аналізу і синтезу проявляється у порівнянні й систематизації об'єктів. Похідними від аналізу і синтезу є операції абстрагування та узагальнення. Мислення спрямоване на розв'язання конкретного завдання. За змістом та характером завдань мислення поділяють на: конкретно-дійове, наочно-образне, абстрактне; практичне і теоретичне; репродуктивне і творче [2].

Інтегративний підхід із позицій педагогіки полягає в інтеграції змісту, методів і засобів розвитку професійного мислення в освітньому процесі. Забезпечення узгодження змісту навчання в цілому, виявлення умов, конструювання шляхів формування професійного мислення майбутніх фахівців технічних спеціальностей $є$ важливою проблемою професійної педагогіки.

Дослідниця сучасних проблем інтеграції I. Козловська [4] обгрунтовує методологічні засади формування інтегративного мислення, розглядає різноманітні підходи до педагогічних явищ і процесів та визначає три категорії ключових компетентностей як концептуальної бази: автономна дія; інтерактивне використання засобів; уміння функціонувати в соціально гетерогенних групах. У дослідженні розглядається кожен із методологічних принципів, обгрунтовуються базові методологічні та загальнонаукові підходи, що покладено в основу інтегративного мислення.

В основі професійного мислення лежить образ професійної діяльності: знання про предмет, засоби, технологію та трудовий процес [7, с. 438]. Формування професійного мислення майбутніх фахівців технічних спеціальностей в освітньому процесі передбачає вирішення проблемних завдань, аналіз професійних ситуацій, прийняття професійних рішень, вибір способів діяльності тощо.

Під час професійної підготовки майбутні фахівці технічних спеціальностей паралельно вивчають основи фундаментальних, технічних та прикладних наук, а також знайомляться 3 дисциплінами гуманітарного циклу. Не кажучи про суттєві відмінності природничих та гуманітарних наук, які відповідно оперують із науковими поняттями та художніми образами, навіть близькі між собою групи наук (природничі та технічні) відображають дійсність властивими саме їм методами. Ці відмінності практично не враховуються при предметному підході до навчання. 
Тому інтегративний підхід до вивчення різноциклових дисциплін сприятиме формуванню професійного мислення майбутніх фахівців технічних спеціальностей.

Важливим педагогічним аспектом $€$ характеристики професійного мислення майбутніх фахівців технічних спеціальностей. У дослідженні А. Зуєвої [3] визначено ціннісно-мотиваційний, операційно-дійовий, когнітивний, креативний, рефлексивний критерії діагностування професійного мислення. Показниками професійного мислення $\epsilon$ : наявність структури професійних пріоритетів, інтерес до розв'язання практичних проблем; інтереси, потреби, мотиви та мотивація майбутньої професійної діяльності; наявність спонукальних особистісних якостей (бажання досягти успіху,самовираження в професійній діяльності); здатність вирішувати професійно орієнтовані завдання і задачі; володіння мисленнєвими вміннями і навичками на достатньому рівні для вирішення професійних завдань; загальний рівень професійного інтелекту; здатність вирішувати професійно орієнтовані завдання і задачі; володіння мисленнєвими вміннями і навичками на достатньому рівні для вирішення професійних завдань; загальний рівень професійного інтелекту; логічність мислення; рівень розвитку технічного мислення; конструктивне оперування просторовими образами; швидкість мислення; оперативність мислення; унікальність; оригінальність.

Окрім того, ознакою сучасного професійного мислення майбутнього фахівця технічних спеціальностей $\epsilon$ увага до альтернативних точок зору, діалогічність, плюралізм тощо. В одній і тій же ситуації можливі різні рішення виконавців відповідно до їхнього типу професійного мислення.

Зауважимо, що основні властивості професійного мислення формуються у закладі освіти. Саме від рівня сформованості цих властивостей особистості залежить якість підготовки майбутніх фахівців до самостійної професійної діяльності.

Розгляд філософських, психологічних, педагогічних аспектів інтегративного підходу до формування професійного мислення майбутніх фахівців технічних спеціальностей дозволив виокремити такі властивості професійного мислення, які формуються в освітньому процесі:

1. Здатність до постановки нових проблем, чутливість до нового, нових проблем означає, що творча людина здатна самостійно виявляти проблеми. Ій властива інтелектуальна творча ініціатива. Самостійне виокремлення і формулювання проблеми - властивість професійного мислення. На сприйняття світу впливають наявні знання, настановлення, оцінки, почуття, погляди, думки, теорії. Навіть, якщо двоє спостерігають одне й те ж, то сприймають вони його по-різному. Відмінність в їх сприйманні та результатах залежить від того, на які наукові теорії вони спираються.

2. Здатність до аналізу та узагальнення явищ, не пов'язаних між собою очевидним зовнішнім зв'язком, також є властивістю професійного мислення. Людина із професійним мисленням здатна до широкого й змістовного сприйняття професійної діяльності: вона мислять нешаблонно, вирішує завдання через усебічний аналіз умови, узагальнює знайдені способи для вирішення інших завдань.

3. Здатність до професійних дій у різних виробничих ситуаціях визначається різнобічністю професійного мислення. Фахівець може уявити те, що буде отримано завдяки прикладеним зусиллям, здатний планувати засоби досягнення мети й знаходити спосіб отримання необхідного результату.
Він спроможний пов'язати одні речі з іншими, тобто виявити зв'язки явищ дійсності. Кількість цих зв'язків визначає різнобічність професійного мислення. У такій ситуації людина здатна швидко генерувати ідеї.

4. Здатність до моделювання і гнучкого розв'язання проблеми дає змогу швидко переходити від однієї категорії до іншої, від одного способу розв'язання до іншого. Як наслідок - людина спроможна замінювати одні предмети іншими, моделювати їх.

5. Здатність до рефлексії та оригінального підходу у розв'язанні проблеми виявляється в самостійності професійного мислення. Людина може осмислювати свою діяльність, а отже, з'ясувати іiі структуру.

Висновки. Таким чином, формування професійного мислення майбутніх фахівців технічних спеціальностей під час навчання передбачає вирішення проблемних завдань, аналіз ситуацій, прийняття професійних рішень, вибір способів діяльності. Обгрунтовано, що інтегративний підхід до формування професійного мислення означених вище фахівців із різних наукових позицій передбачає:

- із позицій філософії - інтеграцію знань, ідеалів, цілей, сподівань;

- із позицій психології - інтеграцію між окремими процесами мислення, почуттями і волею;

- із позицій педагогіки - інтеграцію змісту, методів і засобів розвитку професійного мислення в освітньому процесі.

Перспективи подальших розвідок у даному напрямі вбачаємо у дослідженні особливостей формування професійного мислення майбутніх фахівців технічних спеціальностей у процесі навчання у закладах вищої освіти.

\section{СПИСОК ВИКОРИСТАНОЇ ЛІТЕРАТУРИ}

1. Ващенко Г. Загальні методи навчання. Київ, Укр. вид. спілка, 1997. 410 с.

2. Гончаренко С. У. Український педагогічний словник. Київ : Либідь, 1997. 376 с.

3. Зуєва А. Б. Результати дослідження сформованості професійного мислення майбутніх техніків-механіків агропромислового виробництва. Оновлення змісту, форм та методів навчання $i$ виховання в закладах освіти : збірник наукових праць. Наукові записки Рівненського державного гуманітарного університету. 2013. Вип. 7 (50). С. 68-71.

4. Козловська I. М. Формування професійного мислення майбутнього фахівця: інтегративно-компетентнісний підхід : навчально-методичний посібник. Київ : Педагогічна думка, 2013. 140 с.

5. Маркова А. К. Психология профессионализма. Москва : Профиздат, 1996. 253 с.

6. Свистун В. І., Зуєва А. Б., Луговська Е. М. Професійне мислення фахівців як проблема професійної педагогіки. Професійна підготовка фахівиів: креативний підхід : монографія / за ред. О. А. Дубасенюк. Житомир : Видавець Євенок О. О., 2017. С. 298-319.

7. Якимович Т. Д. Особливості методики формування інтелектуальних умінь у процесі виробничого навчання. Педагогіка $i$ психологія професійної освіти: результати дослідження і перспективи : зб. наук. праць. Київ : ІСДО, 2003. С. 436-443.

8. Johann Friedrich Herbart aus Oldenburg (17761841). Bearb. von R. Fietz; mit einem Beitrag von K. Marwinski. Oldenburg : Holzberg, 1993. Vol. 2. 116 S.

Дата надходження до редакиї: 10.08.2020 p. 